\title{
Do Application Rates of Wastewater Sewage Sludge Affect the Removal of PAHs from Alkaline Saline Soil?
}

\author{
Fabián Fernández-Luqueño ${ }^{1 *}$, Reyna Mendoza-Cristino ${ }^{1}$, Luc Dendooven ${ }^{2}$ \\ ${ }^{1}$ Sustainability of Natural Resources and Energy Program, Cinvestav-Saltillo, Coahuila. C.P. 25900, Mexico \\ ${ }^{2}$ Laboratory of Soil Ecology, GIP, Cinvestav, México D.F, C.P. 07360 Mexico
}

Received: 13 May 2016

Accepted: 23 June 2016

\begin{abstract}
The application of wastewater sludge to an alkaline saline soil of Texcoco accelerated removal of polycyclic aromatic hydrocarbons (PAHs), but not always. As part of a study into factors that might affect dissipation of PAHs from soil, the effect of different application rates $(0,3,9,18$, and 36 tons dry sludge ha $\mathrm{a}^{-1}$ ) of wastewater sludge on removal of phenanthrene and anthracene was studied in an alkaline saline soil with $\mathrm{pH} 9.7$ and electrolytic conductivity (EC) of $7.6 \mathrm{dS} \mathrm{m}^{-1}$. The dynamics of phenanthrene, anthracene, ammonium, nitrite, nitrate, and $\mathrm{CO}_{2}$ were monitored for 56 days. Application of wastewater increased the removal rate of the PAHs independent of the concentration applied, and between 70 and $79 \%$ of the phenanthrene and 69 and $79 \%$ of the anthracene was removed after 56 days. Spiking soil with PAHs increased emissions of $\mathrm{CO}_{2}$ while applying sludge further increased it. It was found that the removal of PAHs was initially low as the amount of phenanthrene and anthracene decreased after only 14 days. The addition of wastewater sludge increased the removal of phenanthrene and anthracene, but the effect was independent of the application rate or the PAHs studied. Spiking soil with PAHs increased emissions of $\mathrm{CO}_{2}$ and reduced the amount of $\mathrm{NH}_{4}^{+}$and $\mathrm{NO}_{3}^{-}$in soil.
\end{abstract}

Keywords: environmental health, mineral nitrogen, PAH degradation, soil pollution, soil sustainability

\section{Introduction}

Soil salinity is an environmental problem that threatens croplands in arid regions worldwide while soil pollution grows daily - even in developing countries. Polycyclic aromatic hydrocarbons (PAHs) enter the environment as a result of residential heating; engine, gas, coal, and wood combustion; and oil-spills. Concentrations of PAHs are monitored in the environment

*e-mail: cinves.cp.cha.luqueno@gmail.com because of their possible negative effects on human health [1-2].

Sludge derived from wastewater treatment with its high organic material and nitrogen and phosphorous content is frequently spread on land to restore degraded soils [3]. It is well documented that organic material can accelerate the removal of PAHs when added to soil [4-6]. Wastewater sludge might affect the dissipation of PAHs in soil in different ways. Wastewater sludge contains larger amounts of organic material that will increase microbial activity, which might accelerate the removal of PAHs from soil. It contains nutrients such as 
$\mathrm{N}$ and $\mathrm{P}$ that might increase microbial activity and thus dissipate PAHs from soil, and is rich in microorganisms that might contribute to the removal of PAHs from soil. Additionally, sludge might change soil conditions, such as $\mathrm{pH}$ and electrolytic conductivity (EC), thereby stimulating or inhibiting removal of PAHs. The question remains if the amount of wastewater sludge applied to a soil will affect the removal of phenanthrene (Phen) and anthracene (Anthra). As part of a study into the removal of PAHs from an alkaline saline soil using organic wastes, soil of the former lake Texcoco with EC 7.6 dS m-1 and $\mathrm{pH} 9.7$ was spiked with Phen and Anthra and amended with 0 , $1.5,4.5,9$, or $18 \mathrm{~g}$ dry wastewater sludge $\mathrm{kg}^{-1}$, i.e., $0,3,9$, 18 , and 36 tons dry sludge ha ${ }^{-1}$, which was equivalent to approximately $0,50,150,300$, and $600 \mathrm{~kg} \mathrm{~N}^{-1}$ added to the $0-15 \mathrm{~cm}$ soil layer with density $1.3 \mathrm{~kg} \mathrm{dm}^{3}$, considering that $40 \%$ of the organic $\mathrm{N}$ was mineralized. Emissions of $\mathrm{CO}_{2}$; concentrations of inorganic $\mathrm{N}$ (ammonium $\left(\mathrm{NH}_{4}^{+}\right.$), nitrite $\left(\mathrm{NO}_{2}^{-}\right)$, and nitrate $\left(\mathrm{NO}_{3}^{-}\right)$; and Phen and Anthra were monitored in an aerobic incubation at $22 \pm 2^{\circ} \mathrm{C}$ for 56 days. The objective of this study was to investigate if the amount of wastewater sludge added to an alkaline-saline soil accelerated the removal of Phen and Anthra.

\section{Material and Methods}

\section{Area Description and Soil Sampling}

The sampling site is located in former Lake Texcoco in the valley of México City (México) (N.L. 19³0", W. L. $98^{\circ} 53^{\prime}$ ). Soil was sampled at random by augering the $0-15 \mathrm{~cm}$ top-layer of three plots of approximately 0.5 ha. The soil from each plot was pooled so that three soil samples were obtained, with $5 \mathrm{~mm}$ sieved and characterized. Characteristics of the soil are given in Table 1.

\section{PAH and Sludge Characteristics}

Hydrocarbons were obtained from Sigma (USA) with purity $>98 \%$ for Phen and $>97 \%$ for Anthra. Acetone was purchased from J. T. Baker (USA) with purity $99.7 \%$. Sludge was obtained from Reciclagua (Sistema Ecológico de Regeneración de Aguas Residuales Ind., S. A. de C. V.) in Lerma, State of México (México). Thirty kg aerobically digested industrial sludge was sampled aseptically in plastic bags. Some characteristics of the sludge can be found in Table 1.

\section{Treatments and Experimental Set-Up}

Sub-samples (90) of $5 \mathrm{~g}$ dry soil of each plot $(n=3)$ were added to $120 \mathrm{ml}$ glass flasks and contaminated with $2 \mathrm{ml}$ acetone in which PAHs were dissolved. An additional 18 sub-samples were not contaminated and served as control. All the flasks were placed under vacuum in a desiccator for $20 \mathrm{~min}$, removed, and $15 \mathrm{~g}$ soil was added to each flask. The soil was then mixed thoroughly. The
Table 1. Characteristics of the Texcoco soil and the wastewater sludge.

\begin{tabular}{|c|c|c|}
\hline & $\begin{array}{c}\text { Texcoco } \\
\text { soil }\end{array}$ & $\begin{array}{c}\text { Wastewater } \\
\text { sludge }\end{array}$ \\
\hline $\mathrm{pH}_{\mathrm{H}_{2} \mathrm{O}}$ & 9.7 & 8.4 \\
\hline Water holding capacity $\left(\mathrm{g} \mathrm{kg}^{-1}\right)^{\mathrm{a}}$ & 569 & $\mathrm{ND}^{\mathrm{b}}$ \\
\hline Water content $\left(\mathrm{g} \mathrm{kg}^{-1}\right)$ & 12 & 842 \\
\hline Organic carbon $\left(\mathrm{g} \mathrm{kg}^{-1}\right)$ & 58.2 & 509 \\
\hline Inorganic carbon $\left(\mathrm{g} \mathrm{kg}^{-1}\right)$ & 24 & ND \\
\hline Total Kjeldahl nitrogen $\left(\mathrm{g} \mathrm{kg}^{-1}\right)$ & 0.6 & 55.3 \\
\hline $\mathrm{N}-\mathrm{NH}_{4}^{+}\left(\mathrm{mg} \mathrm{kg}^{-1}\right)$ & 13.7 & 6127 \\
\hline $\mathrm{N}^{-\mathrm{NO}_{3}^{-}}\left(\mathrm{mg} \mathrm{kg}^{-1}\right)$ & 3.5 & 48 \\
\hline $\mathrm{N}-\mathrm{NO}_{2}^{-}\left(\mathrm{mg} \mathrm{kg}^{-1}\right)$ & 1.3 & 16 \\
\hline Electrolytic conductivity $\left(\mathrm{dS} \mathrm{m}^{-1}\right)$ & 7.6 & 14 \\
\hline Clay content $\left(\mathrm{g} \mathrm{kg}^{-1} \mathrm{l}\right)$ & 24 & ND \\
\hline Silt content $\left(\mathrm{g} \mathrm{kg}^{-1}\right)$ & 103 & ND \\
\hline Sand content $\left(\mathrm{g} \mathrm{kg}^{-1}\right)$ & 873 & ND \\
\hline Textural soil classification & $\begin{array}{l}\text { Loamy } \\
\text { sand }\end{array}$ & ND \\
\hline PAHs & NDET $^{\mathrm{c}}$ & NDET \\
\hline
\end{tabular}

${ }^{\mathrm{a}}$ On a dry base, $\quad{ }^{\mathrm{b}}$ Not determined, $\quad{ }^{\mathrm{c}}$ Not detected.

amount of PAHs added to the $20 \mathrm{~g}$ soil was such that 1,200 mg Phen $\mathrm{kg}^{-1}$ and $520 \mathrm{mg}$ Anthra $\mathrm{kg}^{-1}$ were applied.

Eighteen of the contaminated soil-samples were amended with $1.5 \mathrm{~g}$ dry sludge $\mathrm{kg}^{-1}, 18$ with $4.5 \mathrm{mg}$ dry sludge $\mathrm{kg}^{-1}, 18$ with $9 \mathrm{~g}$ dry sludge $\mathrm{kg}^{-1}$, and 18 with $18 \mathrm{~g}$ dry sludge $\mathrm{kg}^{-1}$, while 18 were left unamended. Sludge water was removed by air drying. The amount of wastewater added was such that approximately $0,50,150,300$, and $600 \mathrm{~kg} \mathrm{~N} \mathrm{ha}{ }^{-1}$ was added considering a soil density of $1.3 \mathrm{~kg} \mathrm{dm}^{3}$ for a $15 \mathrm{~cm}$ soil layer and $40 \%$ of the organic $\mathrm{N}$ was mineralized during the experiment. Proportional amounts of distilled water were then added to all treatments so that the same water content (approximately 40\% WHC) was obtained in each treatment.

Three flasks were chosen at random from each treatment of the three plots. Ten g soils were extracted for inorganic-N with $100 \mathrm{ml} 0.5 \mathrm{M} \mathrm{K}_{2} \mathrm{SO}_{4}$ solution, shaken for $30 \mathrm{~min}$, filtered through Whatman no. 42 filter paper and analyzed, while $1.5 \mathrm{~g}$ soil was extracted for PAHs with acetone and analyzed on a gas chromatograph (GC). These provided zero-time samples.

The remaining flasks were placed in $945 \mathrm{ml}$ glass jars containing a vessel with $10 \mathrm{ml}$ distilled $\mathrm{H}_{2} \mathrm{O}$ and a vessel with $20 \mathrm{ml} 1 \mathrm{M} \mathrm{NaOH}$ to trap evolved $\mathrm{CO}_{2}$. The jars were sealed and stored in the dark at $22 \pm 2^{\circ} \mathrm{C}$ for 56 days. An additional 15 jars containing a vessel with $10 \mathrm{ml}$ distilled $\mathrm{H}_{2} \mathrm{O}$ and a vessel with $20 \mathrm{ml} 1 \mathrm{M} \mathrm{NaOH}$ were sealed and served as controls to account for the $\mathrm{CO}_{2}$ trapped from the atmosphere. After 3, 7, 14, 28, and 56 days, three jars were 
selected at random from each treatment and the soil was analyzed for $\mathrm{NH}_{4}^{+}, \mathrm{NO}_{2}^{-}, \mathrm{NO}_{3}^{-}$, and PAHs as mentioned before. The remaining flasks were opened and aired each of three days for $10 \mathrm{~min}$ to avoid anaerobicity, then sealed again and further incubated. Chemical methodologies were carried out according to [4].

\section{Chemical Analysis}

Concentrations of Phen and Anthra in the soil were analyzed using an ultrasonic extraction method developed by [5]. The $1.5 \mathrm{~g}$ sub-sample of soil was mixed with $3 \mathrm{~g}$ anhydrous sodium sulphate to form a fine powder, placed in a Pyrex tube, and $5 \mathrm{ml}$ acetone was added. The tubes were placed in a sonicated bath at $35-40^{\circ} \mathrm{C}$ for $20 \mathrm{~min}$, mechanically shaken on a vortex for $15 \mathrm{~s}$, and sonicated again for $20 \mathrm{~min}$. The extracts were separated from the soil by centrifugation at $3,000 \times \mathrm{rpm}$ for $15 \mathrm{~min}$. This process was repeated three times. The extracts were combined, evaporated in a fume-cupboard at $50^{\circ} \mathrm{C}$, and dissolved in $2 \mathrm{ml}$ acetone. From each tube, a $2.0 \mu \mathrm{l}$ aliquot was immediately analyzed for PAHs on a Hewlett-Packard 4890-D GC (USA) fitted with a flame ionization detector. An HP-5 column from HewlettPackard (USA) with length of $15 \mathrm{~m}$, inner diameter $0.53 \mathrm{~mm}$, and film thickness $1.5 \mu \mathrm{m}$ was used to separate the PAHs with $\mathrm{He}$ carrier gas flowing at a rate of $7 \mathrm{ml} \mathrm{min}-1$. The oven temperature at $140^{\circ} \mathrm{C}$ was increased to $170^{\circ} \mathrm{C}$ at a rate of $2^{\circ} \mathrm{C} \min ^{-1}$, maintained at $170^{\circ} \mathrm{C}$ for $5 \mathrm{~min}$, and increased to $280^{\circ} \mathrm{C}$ at $30^{\circ} \mathrm{C} \mathrm{min}{ }^{-1}$ and maintained at $280^{\circ} \mathrm{C}$ for $10 \mathrm{~min}$. The temperature of the injector was $280^{\circ} \mathrm{C}$ and that of the detector $300^{\circ} \mathrm{C}$ [6].

The percentage recovery of the PAHs was tested by adding $1.5 \mathrm{~g}$ dry soil of each of the three soil samples (in triplicate) to a Pyrex tube and spiking them with 1,200 $\mathrm{mg}$ phenanthrene $\mathrm{kg}^{-1}$ dry soil and $520 \mathrm{mg}$ anthracene $\mathrm{kg}^{-1}$ dry soil. The PAHs in the soil were then extracted for the added PAHs as described by [4]. The recovery for Anthra and Phen was 96\%.

\section{Statistical Analyses}

Concentrations of $\mathrm{CO}_{2}, \mathrm{NH}_{4}^{+}, \mathrm{NO}_{2}^{-}, \mathrm{NO}_{3}^{-}$, Phen, and Anthra were subjected to one-way analysis of variance using PROC GLM [7] to test for significant differences between treatments and the least significance difference (MSD) was then calculated [7].

\section{Results}

The emission of $\mathrm{CO}_{2}$ resembled zero-order kinetics in all treatments (Fig. 1a). Contaminating soil with PAHs increased the $\mathrm{CO}_{2}$ emission rate $>$ five-fold. Application of wastewater sludge further increased $\mathrm{CO}_{2}$ emissions. Spiking soil with Anthra and Phen increased $\mathrm{CO}_{2}$ emissions significantly.

The concentration of Phen decreased in all treatments after 14 days (Fig. 1b), except for the PAH-spiked soil
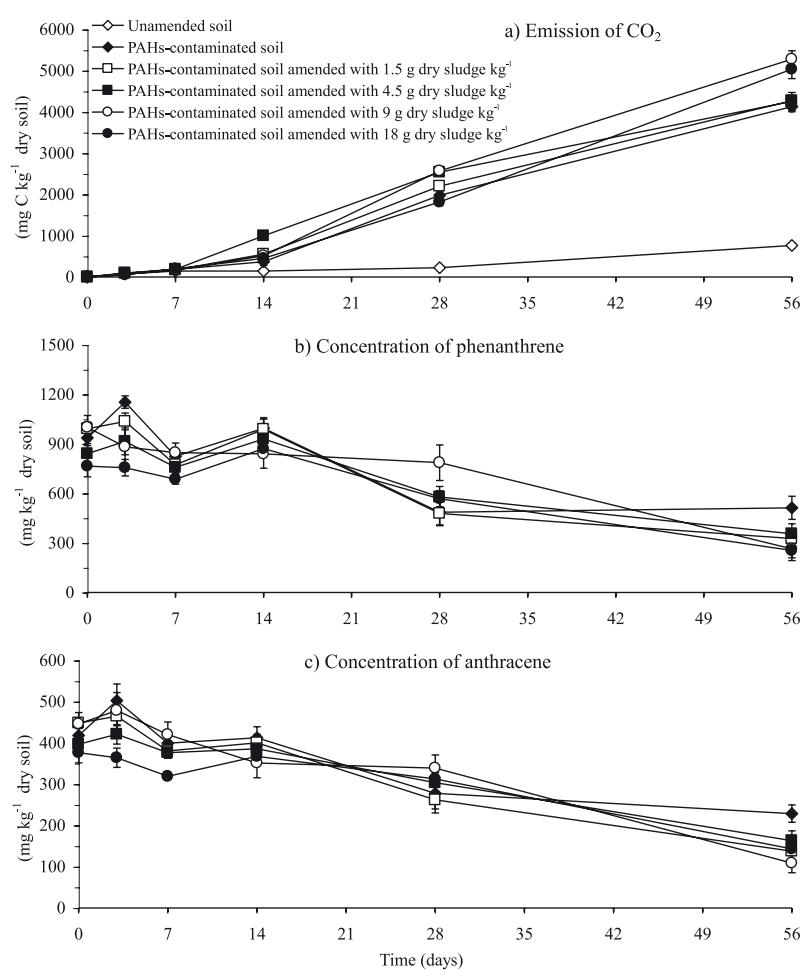

Fig. 1. Emissions of $\mathrm{CO}_{2}\left(\mathrm{mg} \mathrm{C} \mathrm{kg}^{-1}\right.$ dry soil) and concentrations of phenanthrene and anthracene ( $\mathrm{mg} \mathrm{kg}^{-1}$ dry soil) from unamended soil and soil spiked with PAHs and amended with wastewater sludge at $0,1.5,4.5,9$, or $18 \mathrm{~g}$ dry sludge $\mathrm{kg}-1$. The soil was incubated aerobically at $22 \pm 2^{\circ} \mathrm{C}$ for 56 days. Bars are standard errors of the estimates $(\mathrm{p}<0.05)$ and each point in the graph is the mean of three plots and three replicates, i.e., $n=9$.

Table 2. Removal rates of phenanthrene and anthracene (mg $\mathrm{kg}^{-1}$ soil day $\left.{ }^{-1}\right)$ and $\mathrm{CO}_{2}$ emission rates $\left(\mathrm{mg} \mathrm{C} \mathrm{kg}^{-1}\right.$ soil day $\left.{ }^{-1}\right)$ in soil amended with or without wastewater sludge incubated aerobically at $25 \pm 2^{\circ} \mathrm{C}$ for 56 days.

\begin{tabular}{|c|c|c|c|}
\hline & $\begin{array}{c}\mathrm{CO}_{2} \\
\text { emission } \\
\text { rate }\end{array}$ & $\begin{array}{c}\text { Phenan- } \\
\text { threne }\end{array}$ & $\begin{array}{c}\text { Anthra- } \\
\text { cene }\end{array}$ \\
\hline Treatment & \multicolumn{3}{|c|}{$\left(\mathrm{mg} \mathrm{kg}^{-1}\right.$ day $\left.^{-1}\right)$} \\
\hline Unamended soil & $12.7 \mathrm{E}$ & $\mathrm{ND}$ & $\mathrm{ND}$ \\
\hline Soil spiked with PAHs & $70.3 \mathrm{D}$ & $-8.7 \mathrm{~B}$ & $-3.9 \mathrm{~B}$ \\
\hline $\begin{array}{c}\text { Soil + PAHs + sludge } \\
\text { at } 50\end{array}$ & $74.4 \mathrm{CD}$ & $-11.4 \mathrm{AB}$ & $-5.3 \mathrm{~A}$ \\
\hline $\begin{array}{c}\text { Soil + PAHs + sludge } \\
\text { at } 150\end{array}$ & $77.9 \mathrm{BC}$ & $-10.6 \mathrm{AB}$ & $-4.8 \mathrm{AB}$ \\
\hline $\begin{array}{c}\text { Soil + PAHs + sludge } \\
\text { at } 300\end{array}$ & $90.2 \mathrm{~A}$ & $-10.6 \mathrm{AB}$ & $-5.3 \mathrm{~A}$ \\
\hline $\begin{array}{c}\text { Soil + PAHs + sludge } \\
\text { at } 600\end{array}$ & $81.7 \mathrm{~B}$ & $-12.5 \mathrm{~A}$ & $-5.2 \mathrm{~A}$ \\
\hline SEE & 3.1 & 1.6 & 0.6 \\
\hline
\end{tabular}

a SEE: standard error of the estimate $(\mathrm{P}<0.05)$,

${ }^{\mathrm{b}}$ values with the same letter are not significantly affected by treatment, i.e. within columns $(\mathrm{P}<0.05)$. 
amended with $9 \mathrm{~g}$ dry sludge $\mathrm{kg}^{-1}$. In the unamended soil, i.e., in the untreated soil, $57 \%$ of the Phen was removed from soil after 56 days. Applying wastewater sludge increased the removal rate of Phen from soil significantly compared to the unamended soil after 56 days $(\mathrm{P}<0.05)$. However, the amount of wastewater sludge applied had no significant effect on the amount of Phen removed after 56 days and between 70 and $79 \%$ of the Phen was removed (Table 2; Fig. 1).

The concentration of Anthra decreased in all treatments after 14 days (Fig. 1c), except for the PAH-spiked soil amended with $9 \mathrm{~g}$ dry sludge $\mathrm{kg}^{-1}$. In the unamended soil, i.e., in the untreated soil, $56 \%$ of the Anthra was removed from soil after 56 days. The application of wastewater sludge increased the removal rate of Anthra from soil significantly compared to the unamended soil after 56 days $(\mathrm{P}<0.05)$. However, the amount of wastewater sludge applied had no significant effect on the amount of Anthra removed after 56 days, and between 69 and $79 \%$ of the Anthra was removed (Table 2; Fig. 1).

The concentration of $\mathrm{NH}_{4}^{+}$dropped sharply within the first three days in the sludge-amended soil (Fig. 2a). After 14 days, concentrations of $\mathrm{NH}_{4}^{+}$were $<7 \mathrm{mg} \mathrm{N} \mathrm{kg}^{-1}$ and not significantly different among the treatments. Concentrations of $\mathrm{NO}_{2}^{-}$were $<2 \mathrm{mg} \mathrm{N} \mathrm{kg}^{-1}$ and not significantly different among the treatments (Fig. 2b). $\mathrm{NO}_{3}{ }^{-}$concentration increased significantly over time in the
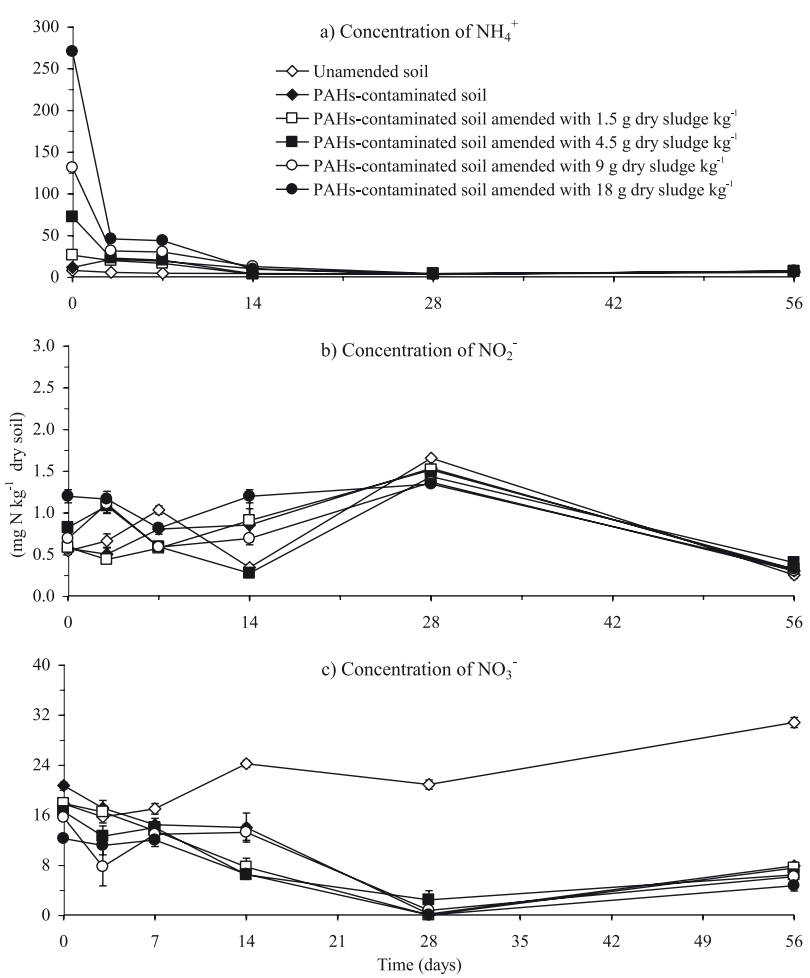

Fig. 2. Concentrations of $\mathrm{NH}_{4}^{+}, \mathrm{NO}_{2}^{-}$, and $\mathrm{NO}_{3}^{-}\left(\mathrm{mg} \mathrm{N} \mathrm{kg}^{-1}\right.$ dry soil) from unamended soil and soil spiked with PAHs, and amended with wastewater sludge at $0,1.5,4.5,9$, or $18 \mathrm{~g}$ dry sludge $\mathrm{kg}-1$. The soil was incubated aerobically at $22 \pm 2^{\circ} \mathrm{C}$ for 56 days. Bars are standard errors of the estimates $(\mathrm{p}<0.05)$ and each point in the graph is the mean of three plots and three replicates, i.e., $\mathrm{n}=9$. uncontaminated soil (Fig. 2c). In soil spiked with PAHs, the concentration of $\mathrm{NO}_{3}-$ decreased over time and reached a minimum after 28 days. Afterward, the concentration of $\mathrm{NO}_{3}{ }^{-}$increased again. The application of wastewater sludge to the PAHs spiked soil had no significant effect on the concentrations of $\mathrm{NO}_{3}^{-}$independent of the amount added.

Concentrations of $\mathrm{NH}_{4}^{+}$decreased sharply in the wastewater sludge-amended soil. Decreases in concentrations of $\mathrm{NH}_{4}^{+}$might be due to nitrification, microbial immobilization, $\mathrm{NH}_{4}^{+}$fixation, or $\mathrm{NH}_{3}$ volatilization. Nitrification did not contribute to the decrease in $\mathrm{NH}_{4}^{+}$as concentrations of $\mathrm{NO}_{3}^{-}$did not increase in the wastewater sludge-amended soil (Fig. 2).

\section{Discussion}

Scelza et al. [8] found similar results and reported a rapid increase in soil respiration and microbial biomass in a soil added with Phen, which suggested that microbial growth and activity had increased. However, Yang et al. [9] reported that the soil microbial activity was inhibited in a soil contaminated with phenanthrene. Acetone used as carrier to spike the soil with Anthra and Phen can be used as C substrate by soil microorganisms, such as Rhodococcus sp EC1, so that emission of $\mathrm{CO}_{2}$ increases [10]. Acetone can also kill soil microorganisms so that microbial activity and thus emissions of $\mathrm{CO}_{2}$ are inhibited, but the killed microorganisms might also serve as a C-substrate for the surviving microorganisms, thereby increasing emissions of $\mathrm{CO}_{2}[11]$.

Autochthonous microorganisms can remove PAHs from soil [12], even in the presence of salt [13] and at $\mathrm{pH}>10$ [14]. This was confirmed in this experiment as approximately $55 \%$ of the Phen and Anthra was removed from soil after 56 days. Both the physico-chemical characteristics of contaminants as well as the physical, chemical, and biological properties of soils affect the degradation of PAHs [4]. However, some of the results indicated that the removal of the PAHs in this experiment was low. First, the removal of PAHs is normally most accentuated in the first days after spiking the soil and further decreases are normally small. Betancur-Galvis et al. [15] found that $33 \%$ of added Phen was removed from an agricultural soil in seven days and an additional $15 \%$ in the next 105 days. The effect was even more outspoken in Texcoco soil with EC $12 \mathrm{dS} \mathrm{m}^{-1}$ and $\mathrm{pH} 10$, as $25 \%$ of Phen was removed within seven days and only $4 \%$ in the next 105 days. In the experiment reported here, a significant decrease in the concentration of Phen was only observed after 14 days. Second, the percentage of removal of Anthra and Phen was similar in this experiment, although the removal of Phen is normally higher than that of Anthra. Betancur-Galvis et al. [15] stated that only $16 \%$ of added Anthra was removed from an agricultural soil, and 33\% of Phen in seven days. The slower degradation of Anthra can be attributed to its low solubility in aqueous systems 
( $\left.0.07 \mathrm{mg} \mathrm{l}^{-1}\right)$ compared to that of Phen $\left(1.29 \mathrm{mg} \mathrm{l}^{-1}\right)$, which renders it only slowly available for microbial degradation. It appears that in our experiment, the bio-accessibility of both PAHs was similar so that the difference in solubility did not affect their degradation.

The application of wastewater to Texcoco soil sometimes accelerates removal of Phen from soil, but not always. Fernández-Luqueño et al. [6] reported that in soil of Texcoco with EC $30 \mathrm{dS} \mathrm{m}^{-1}$ or $80 \mathrm{dS} \mathrm{m}^{-1}$, removal of Anthra was not affected by the application of wastewater sludge. However, Betancur-Galvis et al. [15] found that the removal of Phen in wastewater sludge amended soil with EC $12 \mathrm{dS} \mathrm{m}^{-1}$, and $\mathrm{pH} 10$ was $54 \%$ compared to only $25 \%$ in the unamended soil after seven days and $71 \%$ and $29 \%$, respectively, after 112 days. In the experiment reported here the wastewater sludge had less effect on the removal of Phen and Anthra than as reported by Betancur-Galvis et al. [15], but more than found by Fernández-Luqueño et al. [6]. This would indicate that the application of the wastewater sludge from the same treatment plant did not always have the same effect on the removal of Anthra and Phen from soil. It can be speculated that the combination of soil and sludge characteristics will determine the removal of contaminants from soil.

The $\mathrm{pH}$ of the Texcoco soil was 9.7, which will favour $\mathrm{NH}_{3}$ volatilization. In a previous experiment approximately $50 \mathrm{mg} \mathrm{NH}_{4}^{+}$-N was lost through $\mathrm{NH}_{3}$ volatilization and a similar amount of $\mathrm{NH}_{4}^{+}$was fixed on the soil matrix. Additionally, the soil of Texcoco is N-depleted, so it can be speculated that some of the $\mathrm{NH}_{4}^{+}$was immobilized into the microbial biomass considering the large amounts of $\mathrm{CO}_{2}$ emitted. Deni and Penninckx [16] found that the addition of hydrocarbons at a rate of $4 \mathrm{~g} \mathrm{C} \mathrm{kg}^{-1}$ soil stimulated immobilization of $\mathrm{N}$. It is known that the addition of organic material, especially that with large C-to-N ratio, such as acetone and wastewater sludge, will induce $\mathrm{N}$ immobilization [17]. Acetone can be used as $\mathrm{C}$ substrate by soil microorganisms, e.g., Methylobacterium, Rhodococcus, and Arthrobacter [11], but it is N-free so upon decomposition microbial $\mathrm{N}$ immobilization can be induced. In addition, it has to be remembered that wastewater sludge contains nanoparticles and polyacrylamide two factors that might have increased PAH dissipation and modified the soil conditions [18]. However, the application rate of wastewater sludge did not significantly affect PAH dissipation.

\section{Conclusions}

It was found that the removal of PAHs in the studied soil was low at the onset of the experiment as the amount of Phen and Anthra decreased after 14 days, but after 56 days the removal $>55 \%$. Normally, the removal of PAHs is most accentuated in the first days, with subsequent decreases being very low. The removal of Phen and Anthra was similar in our study although the dissipation of the latter is normally much lower than that of the first. The addition of wastewater sludge increased PAH removal, but the effect was independent of the application rate. Spiking soil with PAHs increased $\mathrm{CO}_{2}$ emissions and reduced the amount of $\mathrm{NH}_{4}^{+}$and $\mathrm{NO}_{3}^{-}$in soil.

\section{Acknowledgements}

This research was founded by Cinvestav Saltillo and Cinvestav Zacatenco. We thank Gaudencio Cabrera-Lázaro and Joaquín Méndez-Bautista for technical assistance.

\section{References}

1. KAMAL A., CINCINELlI A., MARTELLINI T., MALIK R.R. A review of PAH exposure from the combustion of biomass fuel and their less surveyed effect on the blood parameters. Environ. Sci. Pollut. R. 22 (6), 4076, 2015.

2. PAWELCZAK M., DAWIDOWSKA-MARYNOWICZ B., OSZYWA B., KOSZALKOWSKA M., KRECIDLO L., KRZYSKO-LUPICKA T. Influence of bioremediation stimulators in soil on development of oat seedlings (Avena sativa) and their aminopeptidase activity. Arch. Environ. Prot. 41 (1), 24, 2015.

3. ANTONIADIS V., KOUTROUBAS S.D., FOTIADIS S. Nitrogen, phosphorus, and potassium availability in manureand sewage sludge-applied soil. Commun. Soil Sci. Plan. 46 (10), 393, 2015.

4. FERNÁNDEZ-LUQUEÑO F., LÓPEZ-VALDEZ F., DENDOOVEN L., LUNA-SUAREZ S., CEBALLOSRAMIREZ J.M. Why wastewater sludge stimulates and accelerates removal of PAHs in polluted soils? Appl. Soil Ecol. 101, 1, 2016.

5. SONG Y.F., OU Z.Q., SUN T.H., TEDILER A., LORINCI G., KETTRUP A. Analytical method for polycyclic aromatic hydrocarbons (PAHs) in soil and plants samples. Chin. J. Appl. Ecol. 6, 92, 1995.

6. FERNÁNDEZ-LUQUEÑO F., THALASSO F., LUNAGUIDO M.L. CEBALLOS-RAMÍREZ J.M., ORDOÑEZRUIZ I.M., DENDOOVEN L. Flocculant in wastewayter affects dynamics of inorganic $\mathrm{N}$ and accelerates removal of phenanthrene and anthracene in soil. J. Environ. Manage. 90 (8), 2813, 2009.

7. SAS Institute. Statistic guide for personal computers. Version 6.04, Edn. SAS Institute, Cary. 1989.

8. SCELZA R., RAO M.A., GIANFREDA L. Effects of compost and of bacterial cells on the decontamination and the chemical and biological properties of an agricultural soil artificially contaminated with phenanthrene. Soil Biol. Biochem. 39 (6), 1303, 2007.

9. YANG H., SU Y.H., ZHU Y.G., CHEN M.M., CHEN D.B., LIU Y.X. Influences of polycyclic aromatic hydrocarbons (PAHs) on soil microbial community composition with or without Vegetation. J. Environ. Sci Heal. A, 42 (1), 65, 2007.

10. LEE E.H., CHO K.S. 2008. Characterization of cyclohexane and hexane degradation by Rhodococcus sp EC1. Chemosphere 71 (9), 1738, 2008.

11. LEE P.H., CHAO K.P. ONG S.K. Solvent-water extraction method for the evaluation of polycyclic aromatic hydrocarbons bioavailability in coal-tar-contaminated soils, Int. J. Environ. Sci. Te. 11 (7), 1999, 2014.

12. NIKOLOPOULOU M., EICKENBUSCH P., PASADAKIS N., VENIERI D., KALOGERAKIS N. Microcosm 
evaluation of autochthonous bioaugmentation to combat marine oil spills. New Biotechnol. 30 (6), 734, 2013.

13. CASTILLO-CARVAJAL L.C., SANZ-MARTIN J.L., BARRAGAN-HUERTAB.E. Biodegradation of organic pollutants in saline wastewater by halophilic microorganisms: a review. Environ. Sci. Pollut. R. 21 (16), 9578, 2014.

14. WANG J.B., WANG C., HUANG Q.Y., DING F., HE X.W. Adsorption of PAHs on the sediments from the yellow river delta as a function of particle size and salinity. Soil Sediment Contam. 24 (2), 103, 2015.

15. BETANCUR-GALVIS L. A., ALVAREZ-BERNAL D., RAMOS-VALDIVIA A.C., DENDOOVEN L. Bioremediation of polycyclic aromatic hydrocarbon-contaminated salinealkaline soils of the former Lake Texcoco. Chemosphere 62 (11), 1749, 2006

16. DENI J., PENNINCKX M.J. Nitrification and autotrophic nitrifying bacteria in a hydrocarbon-polluted soil. Appl. Environ. Microb. 65(9), 4008-13, 1999.

17. BUSBY R.R., TORBERT H.A, GEBHART D.L. Carbon and nitrogen mineralization of non-composted and composted municipal solid waste in sandy soils. Soil Biol. Biochem. 39 (6), 1277, 2007.

18. FERNANDEZ-LUQUEÑO F., LOPEZ-VALDEZ F., VALERIO-RODRÍGUEZ M.F., PARIONA N., HERNÁNDEZLOPEZ J.L., GARCIA-ORTIZ I., LOPEZ-BALTAZAR J., VEGA-SANCHEZ M.C., ESPINOSA-ZAPATA R., ACOSTA-GALLEGOS J.A. Effects of nanofertilizers on plant growth and development, and their interrelationship with the environmental. In: Fertilizers: components, uses in agriculture and environmental impact, LOPEZ-VALDEZ F., FERNANDEZ-LUQUEÑO F. (Eds.), NOVA Science. New York, USA, 211-24, 2014. 